\title{
THE EXCHANGES OF WATER, ELECTROLYTES AND HEAT DURING PHENYLETHYLHYDANTOIN SICKNESS ${ }^{1}$
}

\author{
BY FRED V. ROCKWELL \\ (From the Departments of Pediatrics and Physiology, of the School of Medicine and \\ Dentistry, The University of Rochester, Rochester, New York)
}

(Received for publication October 16, 1934)

Phenylethylhydantoin (nirvanol) has been used since 1919 in the treatment of chorea minor. Its continued ingestion gives rise to a reaction, probably of an allergic nature, which has been described by Ray and Cunningham (1) as follows: "The sedative effects of nirvanol usually appear on the second or third day of its administration. Fever develops on the seventh day, reaches a maximum on the ninth day, and subsides on the eleventh day. On the ninth day, a few reddish-brown maculo-papules appear on the thighs, wrists, or abdomen, the face often appears swollen and flushed, and a pale pink exanthem may appear on the soft palate or buccal mucosa. By the next day or two, the exanthem has become general. It is usually distinctly morbilliform, but somewhat more like urticaria than the rash of measles. Leukopenia was observed in eight of nine cases. A marked eosinophilia was observed in all specimens of blood that were studied during the eruption."

Nirvanol sickness bears a remarkable resemblance to serum sickness. Rackemann, Longcope and Peters (2) studied the exchange of water and chlorides in pneumonia patients who had received horse serum, and they observed a marked transient retention of water and chlorides. Other investigators (3) have at various times observed a similar retention of these substances in febrile diseases, notably lobar pneumonia. The present problem was undertaken in the hope that a controlled study of nirvanol sickness might indicate how general are the changes in metabolism during fever and allergic states.

\section{METHOD OF STUDY}

Patients were maintained in the metabolism ward at the Strong Memorial Hospital, under the

\footnotetext{
1 The expenses of this investigation were defrayed in part by a grant from the Fluid Research Fund of the Rockefeller Foundation.
}

care of specially trained nurses. The patient's day was divided into four periods of six hours each, beginning at 6 a.m. At the beginning of each period, the patient voided into a weighed bottle, and was then himself weighed on a balance sensitive to $\mathbf{5}$ grams. After this, he received a meal of exactly known weight and composition. The diet was entirely liquid, and was made up of distilled water, powdered milk, lactose, cream, eggs, and a small amount of added sodium chloride. In addition, the patient received daily a constant amount of orange juice and distilled water. Urine was divided into twelve-hour specimens, beginning at 6 a.m. Stools were collected in weighed containers. Temperature, pulse, respiration, barometric pressure, and humidity were recorded four times daily.

Complete water balances for each twelve-hour period were estimated by the method of Newburgh, Johnston and Falcon-Lesses (4). Water available to the body included water drunk, water in food, water formed by the oxidation of food, and water liberated by the catabolism of body tissue. Water lost included water of the urine, water of stools, insensible perspiration, and water held by stored food or tissues. Urine samples were wet-ashed, and pooled; stool specimens were dry-ashed. In the urine samples, total nitrogen was determined by the macro-Kjeldhal method, chlorides by the Volhard-Harvey method; sodium was determined gravimetrically as sodium-zincuranyl-acetate, and potassium by the method of Shohl and Bennett (5). The diet was checked for constancy of composition by daily determination of chlorides. The chloride content of the diet was found from day to day to show an average deviation of 0.83 per cent. The above determinations were made on four patients, each over a period of about three weeks, during part of which they received nirvanol. On a fifth patient, a complete acid-base balance of the urine was determined. This involved determination of 
$\mathrm{pH}$ (electrometrically by means of a quinhydrone electrode), chlorides, phosphates, sulfates, ammonia, titratable acidity, and total inorganic base. Total inorganic base was determined by the method of Wright and Allison (6). All the patients were maintained on the diet for several days before nirvanol was started, and remained in the metabolism ward on the constant routine for several days after the reaction had subsided.

\section{Data on a representative case}

Of the first four cases, Case 4 was the most satisfactory. The diet was taken perfectly, and collections were perfect. Also, the patient developed a perfectly typical rash and fever. The findings in the first three cases substantiated those of Case 4 , although the reactions were less severe and the changes observed less pronounced. This patient was a ten year old girl with a previous history of tonsillitis and rheumatic fever; the findings are shown graphically in Figure 1. In interpreting these graphs, it should be remembered that the intake was exactly the same for each twelve hour period; the stools were few in number, formed, practically constant in composition, and must of necessity be neglected in considering the sudden changes in water and electrolyte balance.

Nirvanol, 0.5 gram, was given at noon each day for seven days. Time is plotted beginning with the first day of its administration. Fever

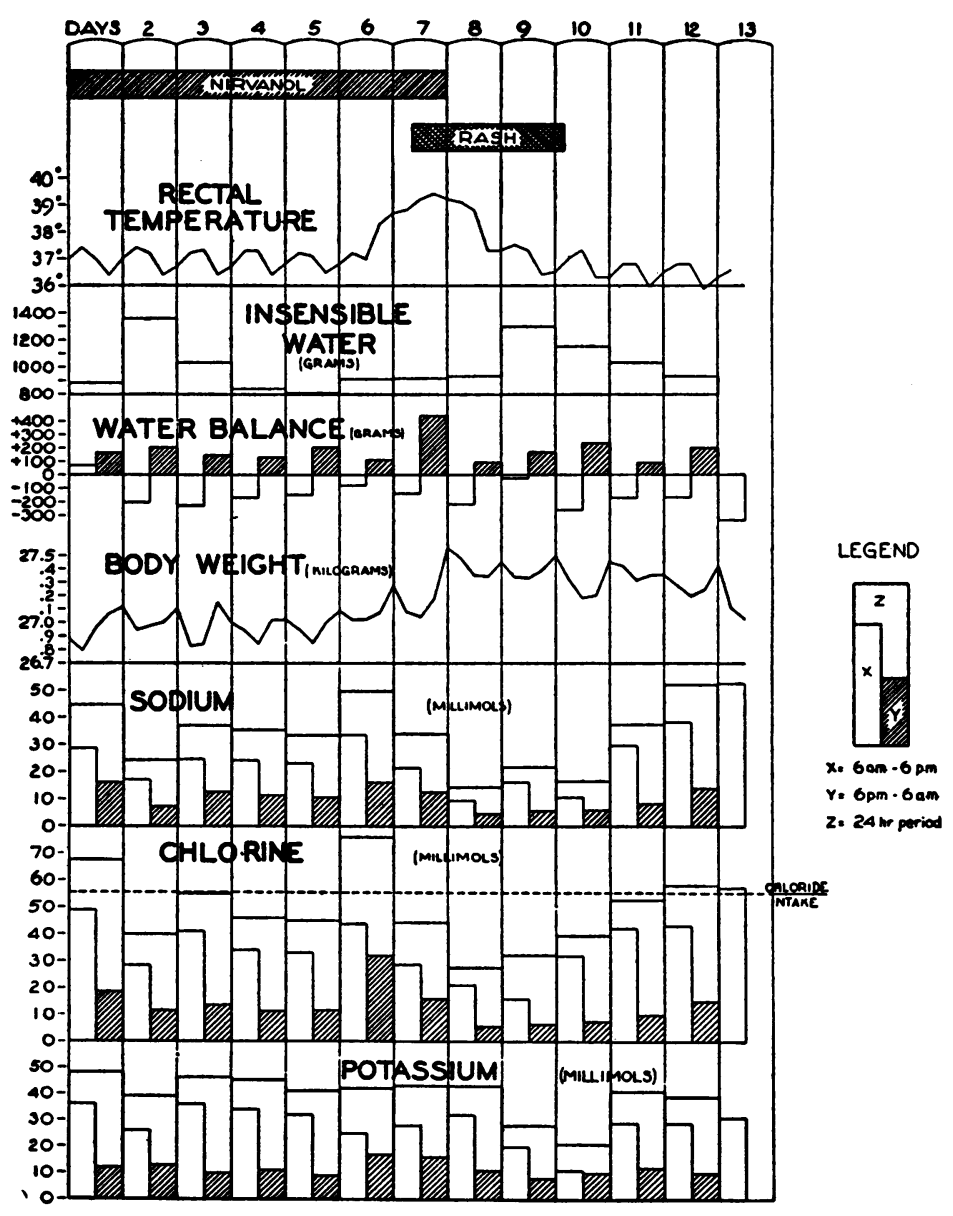

Fig. 1. Subject M. C.

Shaded areas represent the night period. Insensible loss of water is plotted in 24 hour periods, water balance in 12 hour periods. Sodium, chlorine, and potassium are plotted to show day, night, and total 24 hour urinary output in milliequivalents. 
began on the sixth day, and rash on the seventh, as indicated. The insensible loss of water became fairly constant after the first two days, and remained at the same level throughout the fever, showing no significant change until the first postfebrile day, during which there was a pronounced rise. The insensible loss then gradually returned to normal. During this postfebrile period, there was a noticeable tendency for the child to perspire visibly, but moderately. The water balance is the algebraic sum of the water available and the water lost. The water available remained constant within narrow limits throughout the experiment, so that any changes in the water balance are due to changes in the amount of water lost, chiefly through the kidneys.

It will be noted that there was a normal diurnal rhythm in the water balance, as has often been found. During the night period, represented by the shaded areas, there was normally a retention of between one and two hundred grams of water, and a corresponding loss during the day. Changes in water balance were closely paralleled by changes in body weight. A sudden retention of water occurred during the night period of the seventh day, the total water balance for this period being plus 450 grams, and the gain in body weight being 500 grams. This period of retention corresponded to the height of the fever and the beginning of the rash. Subsequently, there was no sharp loss of the retained water, but the weight showed a tendency to return to normal at the end of the experiment. In other cases also there was a similar sudden rise in weight with a gradual retürn to the normal. The total water available for twelve days amounted to 33,882 grams, and the total water lost was 33,748 grams, making a net balance for twelve days of plus 134 grams. The gain of body weight was 160 grams.

The outputs of sodium and of chloride ran closely parallel. They were excreted at a fairly constant rate on the third, fourth, and fifth days. The sudden increase in the output of these elements during the day fever began was observed in only one other case. A definite retention of sodium and chloride occurred on the eighth, ninth, and tenth days. This was interesting, because the retention of water all took place on the seventh day. Hence on the seventh day one must assume that there was at least a slight dilution of the body fluids. The retention of these two elements on days eight, nine, and ten, was far in excess of the loss which occurred on day six.

The output of potassium was remarkably constant for the first eight days. On the ninth and tenth days, there occurred a marked retention. Grouped stool specimens from the period including these days of retention actually contained less potassium than the stools of the normal period. The time relations were again interesting. Water retention occurred on the seventh day, sodium retention began on the eighth day, and potassium retention began on the ninth day. In the other cases studied, the changes in the output of potassium were not nearly so striking, these cases having less severe reactions. Such a retention of potassium is unusual. The fact that the other cases showed only slight retention suggests the possibility of error in the analyses. However, the determinations were checked and rechecked, as many as six determinations being made on the same sample, and no error could be found. It might here be mentioned that throughout the experiments, the patients remained in nitrogen balance, and showed no significant variation in the nitrogen output, indicating that no errors were made in feedings and collections, also that there was no increase in protein catabolism.

According to Gamble et al. (7), knowing the amount of retained sodium and potassium, and their concentrations in the fluids of the body, one can calculate the amount of water that would have to be retained along with the minerals to maintain the isotonicity of the body fluids. Gamble divides the fluid of the body into two portions, one within cell membranes, the other outside cell membranes. The concentration of sodium in extracellular fluids is approximately 148 millimolar; the concentration of potassium in intracellular water is about 112 millimolar. In extracellular water, $\mathrm{K}$ equals about $0.017 \mathrm{Na}$ (in terms of milliequivalents), and in intracellular water, $\mathrm{Na}$ equals about $0.425 \mathrm{~K}$. Let $\mathrm{Na}$ equal the milliequivalents of sodium retained, and $\mathrm{K}$ the milliequivalents of potassium retained by the body. Then the following formulae may be applied: $\frac{\mathrm{Na}-0.425 \mathrm{~K}}{148}$ $=$ liters of extracellular water needed, and 
$\frac{\mathrm{K}-0.017 \mathrm{Na}}{112}=$ liters of intracellular water needed.

The results in Case 4 have been treated as follows: the average urinary output of sodium and potassium for the first five days was considered to be the normal rate of excretion, corresponding to the fixed intake. The next five days included the period of the drug reaction, and any diminution in the output of minerals has been interpreted as a retention of these minerals within the body. Normal water balance for the ten-day period was assumed to be zero, and any deviation from this was considered to be water retained or lost from the body. The results of calculations are summarized in Table I. The agreement between the

TABLE I

Summary of calculations on Case 4

All figures for $\mathrm{Na}$ and $\mathrm{K}$ are in milliequivalents.

\begin{tabular}{c|c|c|c|c|c}
\hline \hline Period & $\begin{array}{c}\text { Average } \\
\text { output of } \\
\text { Na per } \\
\text { day }\end{array}$ & $\begin{array}{c}\text { Average } \\
\text { output of } \\
\mathbf{K} \text { per } \\
\text { day }\end{array}$ & $\begin{array}{c}\text { Retained } \\
\mathrm{Na}\end{array}$ & $\begin{array}{c}\text { Retained } \\
\mathbf{K}\end{array}$ & Remarks \\
\hline $\begin{array}{c}m . E q . \\
\text { 1st 5 } \\
\text { days }\end{array}$ & 35.0 & $\begin{array}{c}m . E q . \\
43.6\end{array}$ & 0 & 0 & $\begin{array}{l}\text { Normal } \\
\text { period }\end{array}$ \\
\hline $\begin{array}{c}\text { 2nd 5 } \\
\text { days }\end{array}$ & 27.2 & 35.4 & 39.0 & 41.0 & $\begin{array}{l}\text { Period of } \\
\text { reaction }\end{array}$ \\
\hline
\end{tabular}

Water needed for retained $\mathrm{Na} \ldots \ldots \ldots \ldots, 146$ cc. Water needed for retained $\mathrm{K} \ldots \ldots \ldots \ldots \ldots . . . .357 \mathrm{cc}$.

Total water needed $. . \ldots \ldots \ldots \ldots \ldots \ldots \ldots . \overline{503}$ cc.

Water balance for first ten days ..... 502 grams

theoretical amount of water necessary to maintain isotonicity of the body fluids and the amount actually retained is obviously better than can be expected from the method, and no doubt is accidental. However, it can be said in all fairness, that the figures given are evidence that sodium and potassium were retained in approximately the right amounts to compensate for the dilution of body fluids which apparently took place on the seventh day. In the figures used for calculations, sodium within muscle cells was taken to be equal to 0.425 times the potassium concentration. This is in all probability in error, since the figures were obtained from analyses of whole muscles, and it is likely that much of the sodium found was outside the muscle fiber in the surrounding extracellular fluid.
The mechanism whereby these shifts in water and mineral balance take place during febrile conditions is doubtless very complex. The kidneys probably play an important part. The following hypothesis may be suggested: as a result of the fever or of the action of metabolic products, the circulation to the kidneys is reduced and the kidney threshold for water is raised. The immediate effect of this is to dilute first the blood plasma, and later the intracellular fluids, thus causing a compensatory retention of sodium followed by a retention of potassium. The retention of potassium would be evident only in fevers not accompanied by destruction of tissue proteins and consequent liberation of potassium. The work of Fremont-Smith, Dailey and Thomas (8) has shown clearly that in fever, there is a dilution, both of the blood and the cerebrospinal fluid. This dilution is manifested by changes in specific gravity, total solids, chlorides, protein, and freezing point.

\section{Water balance data on other cases}

Figure 2 shows the results obtained in Case 3. This boy, aged 10, did not develop such a severe reaction as the patient just discussed, and consequently did not show such marked changes in water and mineral metabolism. The chart does show that such changes as did occur were in the same direction as those observed in the case previously described and may be considered as confirmatory evidence. In this patient, at the start of the drug administration, there was a slight upset in water balance, but any effects of this change appeared to be completely gone by the time the drug reaction occurred. Retention of sodium and chloride was fairly definite, while retention of potassium was less definite. Speaking very conservatively, the results in this and in the other three unpublished cases support the results of Case 4.

Figure 3 is a mass plot of all 12-hour water balances and the corresponding gain or loss in body weight. It is printed because it demonstrates the fact that under the conditions of the experiments, any gain or loss of weight is composed almost entirely of water, and that there is no complicating factor of food storage to be considered in interpreting results. It is presented also to suggest to other investigators in similar 


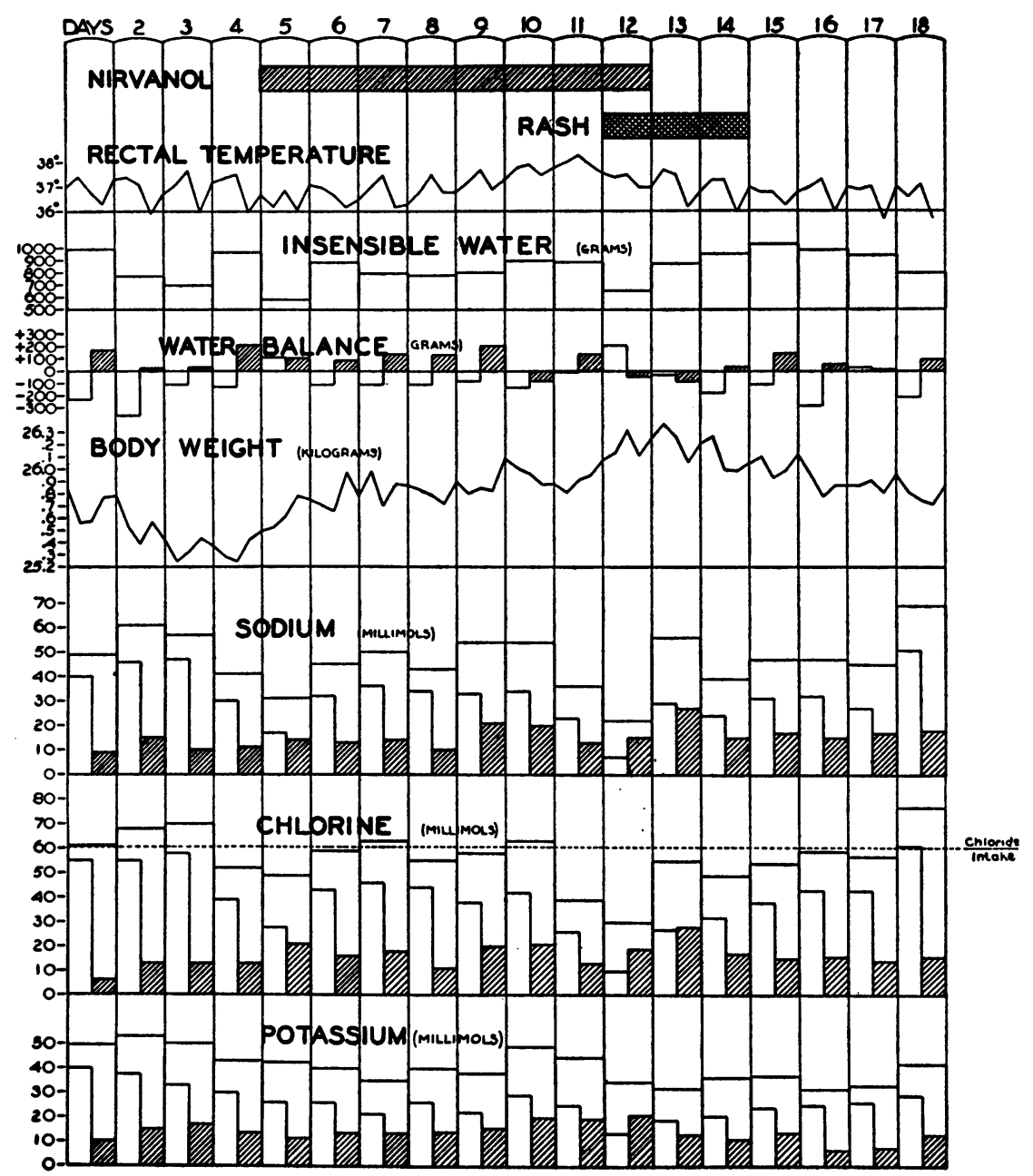

Fig. 2. Subject T. A.

Results plotted as in Figure 1.

fields that under controlled conditions with constant intakes, the gain or loss of body weight corresponds so closely to the total water balance that this last laborious determination may well be omitted without much loss of accuracy.

\section{Acid-base equilibrium}

The work on the fifth case of nirvanol sickness was performed in an effort to learn whether the observed shifts in water balance were accompanied by, or due to, a change in the acid-base equilibrium normally maintained in the body. Beckman (9) has stated that allergy is a state of potential alkalosis. Koehler (10) studied blood $\mathrm{pH}$ and carbon dioxide in cases of influenza with fevers of $103-105^{\circ} \mathrm{F}$. He showed that during such fevers there was a definite alkalosis, the blood $\mathrm{pH}$ going as high as 7.6 ; this was accompanied by a lowering of the alveolar $\mathrm{CO}_{2}$. His conclusions are that the alkalosis during the fever of influenza is the same as that which occurs during voluntary hyperpnea and hot-bath hyperpnea, and is due to the increased lung ventilation. He obtained such an alkalosis in spite of the fact that there was a tendency during the fever toward starvation, which in itself would cause an acidosis.

The fifth case was that of a twelve-year-old girl who had recently had an attack of rheumatic fever. As in the other cases, a complete water balance was calculated for each twelve-hour period, as well as the complete acid-base composition of each twelve-hour urine specimen. The experi- 


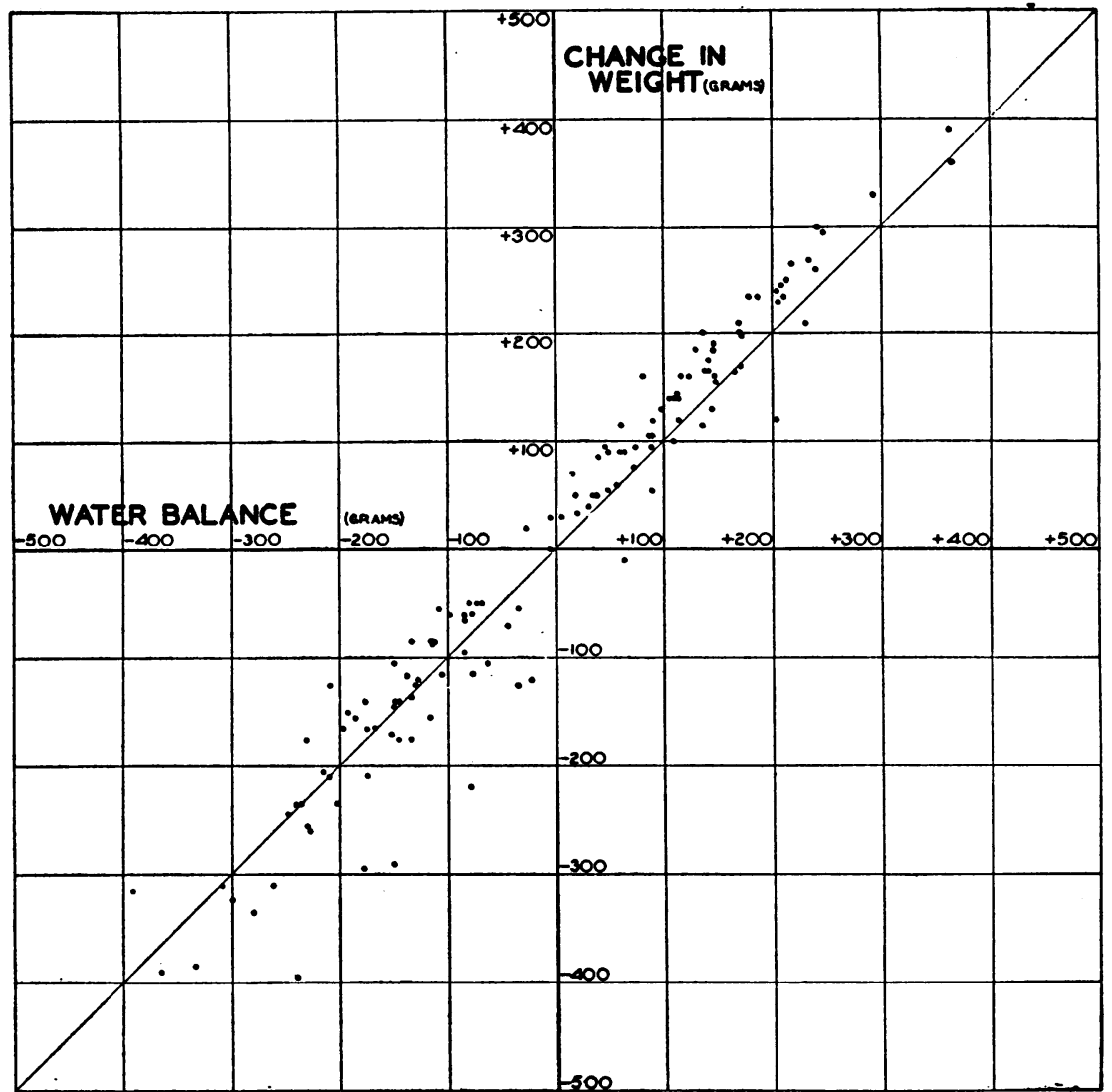

Fig. 3. Total Water Balance for 12 Hour Pertods Is Plotted as the Abscissa Against the Corresponding Change of Body Weight as the OrdiNATE.

ment was marred at the height of the reaction by the inability of the patient to retain all the diet. Up to that time the intake was perfect; collections were perfect throughout. The experimental findings are summarized in Table II.

As in the other cases, the figures given in Table II represent the amounts of the various acid and basic components of the urine excreted per twelve hour period, not the total balance of these substances. Total water balances are given for all periods. Vomiting occurred once during Period $15 \mathrm{y}$, and once during Period 17y. On both occasions the vomitus was saved, the water content determined, and the complete water balance calculated on the basis of the diminished intake. Lowered intake in other periods, as noted, was due to a refusal of food. In such periods, the water balance was also calculated on the basis of the diminished intake, which was accurately known. Since the changes in urinary reaction during the periods in which vomiting occurred were toward the acid side, and since the effect of vomiting itself would be to make the urine more alkaline, we believe that the results obtained were in no way rendered invalid by the accident.

The usual retention during the reaction is not evident in the water balance, although there was a severe rash and accompanying edema around the face. There was, however, a marked disturbance of the normal diurnal rhythm in the period before nirvanol administration. In Period 15y, although the patient refused about one-third of the diet, the balance remained positive. The normal diurnal variation in the urine volume was striking. Of greater interest was the $\mathrm{pH}$ of the urine which exhibited a diurnal variation, being slightly more alkaline during the day. At no time, either in the 
TABLE II

Acid-base composition of the urine in Case 5

Each day is divided into Period x (6 a.m. to 6 p.m.) and Period y (6 p.m. to 6 a.m.). All figures are for 12 hour periods. Rectal temperatures are given for noon in Period $x$, and midnight in Period $y$.

\begin{tabular}{|c|c|c|c|c|c|c|c|c|c|c|c|c|c|c|c|c|}
\hline \multirow[b]{2}{*}{ Date } & \multirow[b]{2}{*}{$\begin{array}{l}\text { Nir- } \\
\text { vanol }\end{array}$} & \multirow[b]{2}{*}{$\begin{array}{l}\text { Rectal } \\
\text { tem- } \\
\text { pera- } \\
\text { ture }\end{array}$} & \multirow[b]{2}{*}{$\begin{array}{l}\text { Water } \\
\text { bal- } \\
\text { ance }\end{array}$} & \multicolumn{9}{|c|}{ Urine } & \multicolumn{4}{|c|}{ Blood Chemistry } \\
\hline & & & & $\begin{array}{c}\text { Total } \\
\text { output }\end{array}$ & $\mathrm{pH}$ & $\begin{array}{l}\text { Titrat- } \\
\text { able } \\
\text { acidity }\end{array}$ & $\begin{array}{c}\text { Am- } \\
\text { monia }\end{array}$ & $\begin{array}{l}\text { Inor- } \\
\text { ganic } \\
\text { base }\end{array}$ & $\begin{array}{l}\text { Chlo- } \\
\text { rides }\end{array}$ & $\begin{array}{c}\text { Inor- } \\
\text { ganic } \\
\text { sul- } \\
\text { phates }\end{array}$ & $\begin{array}{l}\text { Phos- } \\
\text { phates }\end{array}$ & $\begin{array}{l}\text { Or- } \\
\text { ganic } \\
\text { acids }\end{array}$ & $\mathrm{pH}$ & $\begin{array}{l}\text { Bicar- } \\
\text { bonate }\end{array}$ & $\begin{array}{l}\text { Chlo- } \\
\text { rides }\end{array}$ & $\begin{array}{c}\text { Serum } \\
\text { pro- } \\
\text { teins } \\
\text { (refracto- } \\
\text { metric) }\end{array}$ \\
\hline $\begin{array}{l}\text { July } \\
1053\end{array}$ & grams & ${ }^{\circ} \mathrm{C}$ & grams & grams & & m. Eq. & m. Eq. & m. Eq. & m. Eq. & m. Eq. & m. Eq. & m. Eq. & & m. Eq. & per liter & per cent \\
\hline $\begin{array}{l}5 x \\
5 y \\
6 x \\
6 y\end{array}$ & $\begin{array}{l}\mathbf{0} \\
\mathbf{0} \\
\mathbf{0} \\
\mathbf{0}\end{array}$ & $\begin{array}{l}37.3 \\
36.4 \\
37.4 \\
36.4\end{array}$ & $\begin{array}{r}-359 \\
+376 \\
+291 \\
+331\end{array}$ & $\begin{array}{r}1231 \\
575 \\
1149 \\
533\end{array}$ & $\begin{array}{l}5.8 \\
5.3 \\
5.5 \\
5.2\end{array}$ & $\begin{array}{l}13.8 \\
13.7 \\
15.2 \\
13.4\end{array}$ & $\begin{array}{l}17.2 \\
17.8 \\
17.7 \\
17.5\end{array}$ & $\begin{array}{l}71.0 \\
29.7 \\
63.6 \\
26.7\end{array}$ & $\begin{array}{l}46.1 \\
11.4 \\
38.4 \\
11.4\end{array}$ & $\begin{array}{l}19.6 \\
18.0 \\
19.5 \\
18.0\end{array}$ & $\begin{array}{l}25.4 \\
22.9 \\
22.9 \\
21.5\end{array}$ & $\begin{array}{r}18 \\
17 \\
9 \\
15\end{array}$ & & & & \\
\hline $\begin{array}{l}7 x \\
7 y \\
8 x \\
8 y\end{array}$ & $\begin{array}{l}0 \\
0 \\
0.3 \\
0.3\end{array}$ & $\begin{array}{l}37.3 \\
36.6 \\
37.6 \\
36.5\end{array}$ & $\begin{array}{l}-305 \\
+371 \\
-310 \\
+458\end{array}$ & $\begin{array}{r}1160 \\
511 \\
1061 \\
447\end{array}$ & $\begin{array}{l}5.7 \\
5.3 \\
6.0 \\
5.1\end{array}$ & $\begin{array}{l}16.3 \\
13.8 \\
12.7 \\
14.3\end{array}$ & $\begin{array}{l}17.6 \\
17.2 \\
16.3 \\
17.8\end{array}$ & $\begin{array}{l}68.0 \\
24.8 \\
61.6 \\
18.0\end{array}$ & $\begin{array}{r}41.5 \\
10.5 \\
35.6 \\
9.9\end{array}$ & $\begin{array}{l}19.7 \\
18.1 \\
19.4 \\
18.1\end{array}$ & $\begin{array}{l}30.2 \\
20.9 \\
22.1 \\
20.4\end{array}$ & $\begin{array}{r}23 \\
12 \\
6 \\
10\end{array}$ & 7.37 & 27.5 & 99.4 & 7.74 \\
\hline $\begin{array}{c}9 x \\
9 y \\
10 x \\
10 y\end{array}$ & $\begin{array}{l}0.3 \\
0.3 \\
0.3 \\
0.3\end{array}$ & $\begin{array}{l}37.1 \\
36.6 \\
37.3 \\
36.6\end{array}$ & $\begin{array}{l}-254 \\
+402 \\
-168 \\
+322\end{array}$ & $\begin{array}{r}1182 \\
603 \\
1146 \\
689\end{array}$ & $\begin{array}{l}6.0 \\
5.3 \\
5.7 \\
5.3\end{array}$ & $\begin{array}{l}12.6 \\
12.7 \\
14.5 \\
11.3\end{array}$ & $\begin{array}{l}16.4 \\
16.1 \\
16.9 \\
14.3\end{array}$ & $\begin{array}{l}70.8 \\
29.5 \\
59.5 \\
29.5\end{array}$ & $\begin{array}{l}47.8 \\
11.7 \\
31.9 \\
12.7\end{array}$ & $\begin{array}{l}19.5 \\
16.9 \\
18.7 \\
15.8\end{array}$ & $\begin{array}{l}27.1 \\
19.8 \\
24.9 \\
17.6\end{array}$ & $\begin{array}{l}19 \\
17 \\
16 \\
12\end{array}$ & & & & \\
\hline $\begin{array}{l}11 x \\
11 y \\
12 x \\
12 y\end{array}$ & $\begin{array}{l}0.3 \\
0.3 \\
0.3 \\
0.3\end{array}$ & $\begin{array}{l}37.2 \\
36.3 \\
37.3 \\
36.5\end{array}$ & $\begin{array}{l}-336 \\
+192 \\
-164 \\
+196\end{array}$ & $\begin{array}{r}1257 \\
859 \\
1198 \\
730\end{array}$ & $\begin{array}{l}5.6 \\
5.6 \\
6.1 \\
5.3\end{array}$ & $\begin{array}{l}14.9 \\
11.5 \\
10.4 \\
11.2\end{array}$ & $\begin{array}{l}16.9 \\
16.3 \\
15.0 \\
16.8\end{array}$ & $\begin{array}{l}63.8 \\
35.4 \\
70.8 \\
29.5\end{array}$ & $\begin{array}{l}40.0 \\
16.5 \\
43.4 \\
14.9\end{array}$ & $\begin{array}{l}19.2 \\
16.9 \\
17.9 \\
16.7\end{array}$ & $\begin{array}{l}26.2 \\
20.5 \\
22.3 \\
17.4\end{array}$ & $\begin{array}{l}24 \\
14 \\
21 \\
14\end{array}$ & 7.37 & 23.2 & 94.8 & 7.32 \\
\hline $\begin{array}{l}13 x \\
13 y \\
14 x \\
14 y\end{array}$ & $\begin{array}{l}0.3 \\
0.3 \\
0.3 \\
0\end{array}$ & $\begin{array}{l}37.6 \\
37.0 \\
38.8 \\
39.3\end{array}$ & $\begin{array}{r}92 \\
+\quad 79 \\
-192 \\
+175\end{array}$ & $\begin{array}{r}1076 \\
726 \\
1150 \\
785\end{array}$ & $\begin{array}{l}5.5 \\
5.4 \\
5.6 \\
4.9\end{array}$ & $\begin{array}{l}14.4 \\
10.2 \\
11.4 \\
17.9\end{array}$ & $\begin{array}{l}16.6 \\
14.9 \\
15.0 \\
17.0\end{array}$ & $\begin{array}{l}59.2 \\
35.3 \\
57.4 \\
38.4\end{array}$ & $\begin{array}{l}40.4 \\
16.3 \\
75.1 \\
19.8\end{array}$ & $\begin{array}{l}18.2 \\
16.8 \\
18.5 \\
20.2\end{array}$ & $\begin{array}{l}20.5 \\
16.3 \\
17.6 \\
22.4\end{array}$ & $\begin{array}{l}20 \\
12 \\
26 \\
23\end{array}$ & 7.31 & 22.5 & 101.8 & 7.11 \\
\hline $\begin{array}{l}15 x \\
15 y \text { R } \\
16 x \text { R } \\
16 y \text { R }\end{array}$ & $\begin{array}{l}\mathbf{0} \\
\mathbf{0} \\
\mathbf{0} \\
\mathbf{0}\end{array}$ & $\begin{array}{l}39.9 \\
39.3 \\
39.5 \\
37.8\end{array}$ & $\begin{array}{l}-206 \\
+116^{*} \\
+14^{*} \\
+38^{*}\end{array}$ & $\begin{array}{c}1076 \\
332^{*} \\
326^{*} \\
265^{*}\end{array}$ & $\begin{array}{l}5.2 \\
5.0^{*} \\
5.2^{*} \\
4.9^{*}\end{array}$ & $\begin{array}{l}17.7 \\
12.9^{*} \\
10.7^{*} \\
14.7^{*}\end{array}$ & $\begin{array}{l}20.5^{2} \\
17.2^{*} \\
13.1^{*} \\
15.5^{*}\end{array}$ & $\begin{array}{l}52.4^{*} \\
12.8^{*} \\
11.5^{*} \\
10.1^{*}\end{array}$ & $\begin{array}{c}29.2 \\
9.8^{*} \\
6.0^{*} \\
0.4^{*}\end{array}$ & $\begin{array}{l}20.1 \\
16.1^{*} \\
13.0^{*} \\
13.6^{*}\end{array}$ & $\begin{array}{l}23.6^{*} \\
18.8^{*} \\
16.4^{*} \\
20.7^{*}\end{array}$ & $\begin{array}{c}32 \\
5^{*} \\
12^{*} \\
14^{*}\end{array}$ & $\begin{array}{l}7.36 \\
7.33\end{array}$ & $\begin{array}{l}19.2 \\
19.2\end{array}$ & $\begin{array}{l}94.4 \\
91.4\end{array}$ & $\begin{array}{l}7.71 \\
7.78\end{array}$ \\
\hline $\begin{array}{ll}17 x & R \\
17 y & R \\
18 x & R \\
18 y & R\end{array}$ & $\begin{array}{l}\mathbf{0} \\
\mathbf{0} \\
\mathbf{0} \\
\mathbf{0}\end{array}$ & $\begin{array}{l}38.0 \\
38.3 \\
38.2 \\
38.0\end{array}$ & $\begin{array}{l}-308 \\
+133^{*} \\
+64^{*} \\
+104^{*}\end{array}$ & $\begin{array}{r}1335 \\
261^{*} \\
987^{*} \\
425^{*}\end{array}$ & $\begin{array}{l}5.2 \\
5.1^{*} \\
5.6^{*} \\
5.4^{*}\end{array}$ & $\begin{array}{c}18.0^{*} \\
9.7^{*} \\
9.1^{*} \\
6.0^{*}\end{array}$ & $\begin{array}{l}29.9 \\
14.9^{*} \\
21.0^{*} \\
13.5^{*}\end{array}$ & $\begin{array}{r}26.1 \\
6.3^{*} \\
28.8^{*} \\
7.4^{*}\end{array}$ & $\begin{array}{r}7.0 \\
2.0^{*} \\
13.2^{*} \\
4.8^{*}\end{array}$ & $\begin{array}{l}19.1 \\
14.1^{*} \\
15.9^{*} \\
11.5^{*}\end{array}$ & $\begin{array}{c}25.4 \\
13.1^{*} \\
12.5^{*} \\
5.3^{*}\end{array}$ & $\begin{array}{c}10 \\
5^{*} \\
13^{*} \\
6^{*}\end{array}$ & 7.37 & 23.0 & 97.8 & 7.40 \\
\hline $\begin{array}{l}19 x \text { R } \\
19 y \\
20 x \\
20 y\end{array}$ & $\begin{array}{l}\mathbf{0} \\
\mathbf{0} \\
\mathbf{0} \\
\mathbf{0}\end{array}$ & $\begin{array}{l}37.4 \\
36.2 \\
36.8 \\
36.5\end{array}$ & $\begin{array}{l}=1 \\
=50^{*} \\
=88 \\
+175^{*}\end{array}$ & $\begin{array}{c}1032 \\
433^{*} \\
884 \\
421^{*}\end{array}$ & $\begin{array}{l}5.7 \\
5.7^{*} \\
6.1 \\
5.3^{*}\end{array}$ & $\begin{array}{l}8.6 \\
7.3^{*} \\
7.4 \\
9.7^{*}\end{array}$ & $\begin{array}{l}24.4 \\
13.8^{*} \\
23.4 \\
17.9^{*}\end{array}$ & $\begin{array}{l}32.1 \\
15.0^{*} \\
42.1 \\
11.2^{*}\end{array}$ & $\begin{array}{c}15.9 \\
9.8^{*} \\
26.0 \\
6.0^{*}\end{array}$ & $\begin{array}{l}17.0 \\
16.3^{*} \\
17.6 \\
15.6^{*}\end{array}$ & $\begin{array}{l}16.2 \\
11.3^{*} \\
15.4^{*} \\
12.5^{*}\end{array}$ & $\begin{array}{l}21 \\
14^{*} \\
27 \\
12^{*}\end{array}$ & 7.31 & 25.0 & 97.8 & 7.35 \\
\hline
\end{tabular}

$R$ after the date denotes the presence of a skin eruption.

* denotes period of decreased intake of diet.

control period, the period of the drug reaction, or the period of partial starvation, can the $\mathrm{pH}$ be said to vary significantly from the normal, except, perhaps, for a slight tendency to become more acid during the period of diminished intake of the diet. In Periods $14 y$ and $15 x$, there was a small reduction in the $\mathrm{pH}$, hardly enough to be significant. Because of the original low level of the $\mathrm{pH}$ of the urine, any shift of the reaction toward the acid side would be limited.

The titratable acidity and ammonia were quite constant until Periods $14 y$ and $15 x$, during which both were slightly increased. These periods were at the beginning of the fever. During the following periods, when the intake was lowered, there was a corresponding lowering of the excretion of all the elements except ammonia, which was excreted in an amount greater than normal. There was a very marked diminution in the excretion of inorganic base and chlorides during the fever. At least part of this was due to diminished intake, but the output of these electrolytes was decreased much more proportionately than would be expected from the change in the output of phosphates and sulfates.

The output of chlorides in this case, as in Case 4 , increased suddenly just at the beginning of the fever in Period 14x. This fact was remarkable because there was no increase in the excretion of cations to accompany the increased anions in the urine, nor was there any increase in the acidity. All determinations were repeatedly checked to 
rule out the possibility of analytical error. No explanation can be offered at present for this phenomenon. The possibility that the chloride is excreted in combination with some strong organic base suggests itself, but has not been verified.

During the period of decreased intake of food, the ammonia output increased noticeably, apparently to take the place of fixed base. Organic acids could not be determined very accurately and appeared very irregular. The maximum excretion of $32 \mathrm{~m}$. Eq. reached on Period 15x, at the beginning of the fever, while the intake was still constant, may indicate an increased oxidation of fat.

The following interpretation may be placed upon these data. The diet was fairly rich in fat and the $\mathrm{pH}$ of the urine tended normally to be low. It is well known that children develop signs of ketosis and acidosis much more readily than adults. It is also well known that during fever metabolism is increased. In nirvanol fever, the fuel for the increased metabolism is not protein and hence must consist of fat and carbohydrate, and probably in this case consists mostly of fat. The tendency to alkalosis, which Koehler (10) observed during fever in adults, is evidently counteracted by the above mentioned tendencies in children. The results obtained in this case are a combination of the shifts of water and electrolytes which occur during uncomplicated nirvanol fever, plus the effects of partial starvation. The important point is that no sign of any alkalosis can be observed. The results of this work may be taken to indicate that mineral metabolism during allergic states is a matter of hydration and dehydration, not of fundamental changes in the acid-base economy of the body, and that the benefits of acid therapy in allergy may be due to the diuresis and dehydration resulting therefrom.

A few other chemical analyses of the blood have been included in Table II. Bicarbonate was determined gasometrically, chlorides volumetrically, and $\mathrm{pH}$ by means of a special quinhydrone electrode mounted inside a glass syringe. Determinations were made on blood serum, collected under paraffin oil, and protected from contact with the air. Serum protein concentration, determined by a dipping refractometer, showed no significant trend in this particular case. Since this measurement is considerably influenced by changes in se- rum lipids and other factors, not much emphasis should be placed upon it. The $\mathrm{pH}$ remained constant within the limits of experimental error both in the normal period and during the rash and fever. Bicarbonates were significantly lowered during the fever. This was probably, but not necessarily due to their displacement by some other anion. The high value for serum chlorides in Period $13 x$ was interesting in view of the outpouring of chlorides which occurred on the following day. The lowest value for serum chlorides occurred during the height of the fever, but the significance of this was rendered somewhat less clear because of the lowered food intake at this point. These few figures add some confirmation to the finding that there is no trend toward alkalosis during the condition known as nirvanol sickness.

\section{Energy metabolism}

During the study of the exchange of water it was found that the heat lost by vaporization of water remained normal or slightly below during the fever but rose markedly in the two or three days immediately following the cessation of the fever (see Figure 1). It is generally accepted that febrile temperatures are reduced through the mechanism of increased perspiration. In these children with nirvanol fever, insensible loss of water did not increase until after the fever had abated. Therefore, the excess heat produced must have been lost by increased radiation, convection, and conduction. Normally about 75 per cent of the heat produced by the body is lost by these means, and 25 per cent by evaporation of water. For the sake of completeness, studies were made of the energy exchanges of five other patients with nirvanol sickness who were not maintained in the metabolism ward.

Daily measurements were made of basal oxygen consumed and carbon dioxide produced, and simultaneous measurements were made of the rectal and skin temperatures. Skin temperature was measured over the chest and epigastrium by the method devised by Burton (11). This involves the use of a resistance thermometer made by sewing fine nickel wire to the inside of a gauze vest. In still air, the heat lost by a warm body by radiation, convection, and conduction is directly pro- 
portional to the difference between the surface temperature of the body and the temperature of the environment. Changes in relative humidity over a range of 20 to 80 per cent have very little effect on this property of warm objects. Hence by measuring the average skin temperature of a patient and subtracting the room temperature, one can obtain a comparative measure of the heat which is lost by radiation, convection, and conduction. Burton (12) has shown that a measure of the ease with which heat is conducted from the interior of a warm body to the outside can be obtained by calculating the ratio

Excess of skin temperature over room temperature Excess of rectal temperature over skin temperature

Changes in the ease with which heat is conducted from the interior to the exterior are chiefly due to changes in the peripheral blood flow, and accordingly this index is a comparative measure of changes in the circulation of the skin. This index will be referred to as the circulation index, and the numerator of the fraction as the excess temperature.

TABLE III

Subject J. S.

Weight $29.2 \mathrm{kgm}$. Ht. $131 \mathrm{~cm}$. Treated with nirvanol but developed no reaction.

\begin{tabular}{c|c|c|c|c|c|c}
\hline \hline Date & $\begin{array}{c}\text { Room } \\
\text { tem- } \\
\text { pera- } \\
\text { ture }\end{array}$ & $\begin{array}{c}\text { Skin } \\
\text { tem- } \\
\text { pera- } \\
\text { ture }\end{array}$ & $\begin{array}{c}\text { Excess } \\
\text { tem- } \\
\text { pera- } \\
\text { ture }\end{array}$ & $\begin{array}{c}\text { Rectal } \\
\text { tem- } \\
\text { pera- } \\
\text { ture }\end{array}$ & $\begin{array}{c}\text { Circu- } \\
\text { lation } \\
\text { index }\end{array}$ & $\begin{array}{c}\text { Metab- } \\
\text { olism } \\
.\end{array}$ \\
\hline March 198s & ${ }^{\circ}$ C. & ${ }^{\circ}$ C. & ${ }^{\circ}$ C. & ${ }^{\circ} C$. & & $\begin{array}{l}\text { cal. per sq. } \\
\text { m. per hour }\end{array}$ \\
5 & 22.20 & 33.40 & 11.20 & 37.5 & 2.7 & 43.8 \\
6 & 23.15 & 32.15 & 9.00 & 37.0 & 1.9 & 45.1 \\
7 & 27.46 & 33.96 & 6.50 & 37.4 & 1.9 & 45.6 \\
8 & 24.52 & 33.11 & 8.59 & 37.2 & 2.1 & 48.4 \\
9 & 19.38 & 31.25 & 11.87 & 37.5 & 1.9 & 42.4 \\
\hline
\end{tabular}

Table III shows first the results of an experiment which will serve as a control. Boy J. S. received nirvanol but failed to develop any reaction. The room temperature was deliberately varied from day to day. From the table it is apparent that the excess temperature varies with the room temperature, but the circulation index remains relatively constant. These figures show that over the time and temperature range of the experiment, there was no significant alteration by the normal body of the peripheral circulation.
TABLE IV

\section{Subject $W . L$.}

Weight $23.6 \mathrm{kgm}$. Ht. $128 \mathrm{~cm}$. Energy metabolism during nirvanol sickness and a subsequent respiratory infection.

\begin{tabular}{|c|c|c|c|c|c|c|c|}
\hline Date & $\begin{array}{l}\text { Room } \\
\text { tem- } \\
\text { pera- } \\
\text { ture }\end{array}$ & \begin{tabular}{|c} 
Skin \\
tem- \\
pera- \\
ture
\end{tabular} & $\begin{array}{c}\text { Ex- } \\
\text { cess } \\
\text { tem- } \\
\text { pera- } \\
\text { ture }\end{array}$ & $\begin{array}{c}\text { Rec- } \\
\text { tal } \\
\text { tem- } \\
\text { pera- } \\
\text { ture }\end{array}$ & $\begin{array}{l}\text { Cir- } \\
\text { cula- } \\
\text { tion } \\
\text { index }\end{array}$ & $\begin{array}{l}\text { Metab- } \\
\text { olism }\end{array}$ & $\underset{\text { marks }}{\mathrm{Re}-}$ \\
\hline December 1982 & ${ }^{\circ} \mathrm{C}$. & ${ }^{\circ} \mathrm{C}$. & ${ }^{\circ} \mathrm{C}$. & ${ }^{\circ} \mathrm{C}$. & & $\begin{array}{l}\text { Cal. per } \\
\text { sq. m. }\end{array}$ & \multirow{11}{*}{$\begin{array}{l}\text { Rash } \\
\text { Rash } \\
\text { Rash } \\
\text { Rash } \\
\text { gone }\end{array}$} \\
\hline 21 & 25.5 & 33.5 & 8.0 & 36.7 & 2.5 & & \\
\hline 22 & 27.5 & 35.1 & 7.6 & 36.7 & 4.7 & 42.7 & \\
\hline 24 & 28.1 & 36.0 & 7.9 & 37.6 & 4.9 & 44.7 & \\
\hline 25 & 27.2 & 35.9 & 8.7 & 38.2 & 3.7 & 51.9 & \\
\hline 26 & 26.4 & 37.5 & 11.1 & 39.0 & 7.4 & 54.0 & \\
\hline 27 & 27.2 & 37.7 & 10.5 & 38.4 & 15.0 & 45.2 & \\
\hline 28 & 27.5 & 36.9 & 9.4 & 38.6 & 5.5 & 54.1 & \\
\hline 29 & 26.6 & 34.6 & 8.1 & 38.2 & 2.3 & 53.1 & \\
\hline 30 & 27.0 & 35.9 & 8.9 & 38.7 & 3.2 & 45.5 & \\
\hline 31 & 26.7 & 34.3 & 7.6 & 37.2 & $\begin{array}{l}0.2 \\
2.6\end{array}$ & 44.7 & \\
\hline
\end{tabular}

In contrast, Boy W. L. developed a typical reaction lasting three days from December 25, 1932 to December 27, 1932. The second rise in temperature on December 28, 1932 was due to the development of a respiratory infection. From an experimental standpoint this was a fortunate occurrence since it permitted a comparison of the effects of fever, with and without a rash, on the circulation index. In this experiment the room temperature was kept relatively constant. During the nirvanol rash and fever the excess temperature and the circulation index were both significantly increased, while later, during the fever due to the respiratory infection and after the disappearance of the rash, the excess temperature and index returned to normal. This case showed the most pronounced changes; others studied showed changes of lesser magnitude, but in the same direction. From the data observed the conclusion might be drawn that during the abatement of nirvanol fever the excess heat is lost, not by the usual method of increased perspiration, but by increased peripheral circulation, and hence increased loss through radiation, convection, and conduction. The rash and visible flushing of the skin may be considered as the mechanism whereby the increased heat loss is brought about.

The measurements of heat production during the fever have been calculated as per cent of the normal level establishd on each child during the 
afebrile state. Comparison of all the results shows that there is an increase of approximately 13 per cent in the heat produced for each rise of one degree centigrade in the rectal temperature. The exchange of energy during malaria, typhoid, erysipelas, and other fevers has been worked out in great detail by Barr, DuBois, and their coworkers (13) at the Russell Sage Institute. They found in general that the heat production during fever remained at about 20 to 28 per cent above basal except during chills, when it rose to 200 per cent above basal. Fever was maintained because of inadequate increase of heat loss through the skin, not because more heat was produced than can normally be eliminated. This mechanism is apparently common to all fevers, including nirvanol fever.

It may be said therefore that nirvanol fever is due mainly to inadequate increase of heat loss, and is relieved chiefly by a later increase in heat radiated, conveyed, and conducted away from the body. This last process is doubtless brought about by the changes in the peripheral circulation which are evidenced by the erythema during the skin reaction. We infer that in the early stages evaporation is prevented from increasing, and that this is the chief reason for the fever.

\section{SUM MARY}

1. There occurred in phenylethylhydantoin sickness, as in serum sickness, a temporary retention of water, then of sodium and chloride, then of potassium, in the order stated.

2. During the fever, there was a slight tendency toward acidosis, as evidenced by a study of the acid-base equilibrium of the urine. At no time during the reaction did there appear any sign of alkalosis.

3. The rate of oxygen consumption was increased in proportion to the height of the fever.

4. The fuel for the increased heat production was not protein.

5. The fever was relieved by an increase in the heat lost through the channels of radiation, conduction, and convection.

The author wishes to express his gratitude to Dr. E. F. Adolph and Dr. S. W. Clausen for their guidance, and to Dr. A. C. Burton, Miss Augusta McCord and Mr. G. S. McClure for their kind assistance.

\section{BIBLIOGRAPHY}

1. Ray, H. H., and Cunningham, J. S., Phenylethylhydantoin in the treatment of Sydenham's chorea. Am. J. Dis. Child., 1930, 39, 1205.

2. Rackemann, F. M., Longcope, W. T., and Peters, J. P., The excretion of chlorids and water and the renal function in serum disease. Arch. Int. Med., 1916, 18, 496.

3. Peters, J. P., and Van Slyke, D. D., Quantitative Clinical Chemistry. Volume I. Williams and Wilkins Co., Baltimore, 1931, p. 785.

4. Newburgh, L. H., Johnston, M. W., and FalconLesses, M., Measurement of total water exchange. J. Clin. Invest., 1930, 8, 161.

5. Shohl, A. T., and Bennett, H. B., A micro method for the determination of potassium as iodoplatinate. J. Biol. Chem., 1928, 78, 643.

6. Wright, S. L., and Allison, C. L., The determination of total base. J. Biol. Chem., 1933, 100, 1.

7. Gamble, J. L., Ross, G. S., and Tisdall, F. F., The metabolism of fixed base during fasting. J. Biol. Chem., 1923, 57, 633.

8. Fremont-Smith, F., Dailey, M. E., and Thomas, G. W., Dilution of blood and cerebrospinal fluid in fever. J. Clin. Invest. (Proc.), 1928, 6, 9.

9. Beckman, H., Allergy and the acid-base balance. J. A. M. A., 1930, 95, 1582.

10. Koehler, A. E., Acid-base equilibrium. I. Clinical studies in alkalosis. Arch. Int. Med., 1923, 31, 590.

11. Burton, A. C., A new technique for the measurement of average skin temperature over surfaces of the body and the changes of skin temperature during exercise. J. Nutrition, 1934, 7, 481.

12. Burton, A. C., The application of the theory of heat flow to the study of energy metabolism. J. Nutrition, 1934, 7, 497.

13. Barr, D. P., Cecil, R. L., and DuBois, E. F., Clinical calorimetry. XXXII. Temperature regulation after the intravenous injection of proteose and typhoid vaccine. Arch. Int. Med., 1922, 29, 608. 